\title{
The Development Strategy of Main Commodities in Regency of Tuban
}

\author{
Kristiawan ${ }^{1}$., N. Hanani $\mathrm{AR}^{2}$.,Soemarno ${ }^{3}$., and S. Y. Tyasmoro ${ }^{4}$ \\ ${ }^{1}$ Doctoral Program in Environmental Sciences and Development, University of Brawijaya, Malang, Indonesia; \\ ${ }^{2}$ Department of Social Economics, Faculty of Agriculture, University of Brawijaya, Malang, Indonesia \\ ${ }^{3}$ Department of Soil Science, Faculty of Agriculture, University of Brawijaya, Malang, Indonesia. \\ ${ }^{4}$ Department of Environmental Resources, Faculty of Agriculture, University of Brawijaya, Malang, Indonesia.
}

\begin{abstract}
Tuban is one area that has agricultural commodities make a significant contribution to the economy. Agricultural commodities in Tuban include food crops, plantations, forestry, fisheries and livestock. Therefore, this study was conducted with the aim of knowing the horticulture product development strategy by using SWOT and AHP. The results Showed that the strategy should be carried out expand the planting area that will increase of the productivity of vegetables and fruits featured. In addition, by using AHP analysis Showed that the commodity that takes precedence is the Large Red Chilli, Cayenne pepper/Small, star fruit, mango, melon, watermelon, Duku, Citrus, Banana and Guava. The study recommends that the processing should be performed yields superior products that add value and attractiveness increase is, so will be the solution in increasing income and employment in Tuban.
\end{abstract}

Keywords:fruits, SWOT, superior products

\section{Introduction}

Economic empowerment is an important element in creating a major and independent regions aspired through the decentralization policy. Regional economic development can be defined as a process by the which the local Governments and communities to manage existing resources and form a pattern of a partnership between local Governments and the private sector to create a new jobs and stimulate the development of economic activities in the region. Therefore, local government and community participation using existing resources to be Able to assess potential sources of resources required to design and build the economy of the region. Determination of the national and regional commodity is the first step towards the development of agriculture the is based on the concept of efficiency to Achieve comparative and competitive advantages in the face of globalization of trade. Commodity development that has comparative advantages of the supply side is characterized by superiority in growth in biophysical conditions, technological and socio-economic conditions of farmers in the region. In terms of demand, commodity markets are characterized by strong domestic and international demand.

One purpose of the determination of this commodity is that the development of Reviews these commodities are intrinsically has a specific strength based on its comparative advantage within the scope of an area or region could be sharp and focused. (Intercession and Supena, 2000). With the program's preferences based on the development potential of the region is not expected to occur generalization economic development program for each region. Instead there will be specialization program innovation-based economic development potential of existing areas. With the approach of specialization program that is proportional in turn is expected implementation of various programs on regional economic development will be Carried out efficiently, effectively and accurately, which in the end can achieve optimal results. According to Central Bureau of Statistics Tuban, Tuban in economic growth from year to year is quite stable. This is indicated resources by the growth of data Tuban in 2011 roomates Reached 7:08, the year 2012 Reached the figure of 6:36, 7:03 and in 2013 Reached percent.

Regional economic conditions in general can be seen from the figures Regional Domestic Product (GDP), investment, and inflation, taxes and fees, loan and service economy. GDP at current prices (ADHB) Tuban Increased 14.67\% in 2013 from 2012. The GDP Commodity structure of agriculture in a Considerable contribution to the economy in Tuban. Agricultural commodity in Tuban, which include food crops, plantation, forestry, fishery and livestock have different potentials. Therefore, the determination of agricultural commodities needs to prioritize and formulate development strategy so that the potential and contribution of agricultural commodities are not decreasing. Product development strategy set forth above is done by using a SWOT analysis, which is a matching tool of various strategic factors. From the SWOT analysis produces an alternative strategy to develop the potential of horticulture. The results of this study are expected to provide the scientific rationale and strong for Efforts to boost economic growth, in particular the contribution of the agricultural sector in Tuban. 


\section{Basic Theory}

Regional economic development is a process by which local governments and communities to manage resources that exist and form a pattern of partnership between government and the private sector to create new jobs and stimulate the development of economic activity (growth) in the region. The principal issues in regional development is located in its emphasis on development policies based on the uniqueness of the area in question by using the potential of human resources, institutional, and physical resources locally (local). This orientation leads to taking initiatives emanating from the area in the development process to create new employment opportunities and stimulate increased economic activity (Arsyad, 2002).

The success of the development process can be seen from several benchmarks, including economic growth, economic structure and increasingly smaller antarpenduduk income inequality, between regions and between sectors. But the reality of economic growth is not always followed by equalization (Restiatun, 2009). Development does not always run systemically. Some areas experienced rapid growth, while other regions experienced slower growth. Uneven growth and income distribution are not in favor of public welfare is a condition of the majority of regional development in Indonesia today.

Superior product (PUD) in Indonesia for a long time based on government regulations (Riza Alfita, 2009). Featured products area is a superior product that has a characteristic and uniqueness that no other regions as well as the competitiveness reliable and can provide employment opportunities to the local community. Superior product is also environmentally friendly oriented and service-oriented markets both locally and nationally and regionally. Superior product development and empowerment as the economic potential of regional autonomy era is a job that is not easy to implement, it is because the development of PUD is closely linked to the political will or the policy of the Local Government. The role of local government is very necessary and very important in the development and empowerment of superior product as one of the pillars of the regional economy. Therefore, superior product related to some stakeholders who played a role in accordance with their respective authorities.

SWOT Analysis is a strategic planning method used to evaluate the strengths (strengths), weaknesses (weaknesses), opportunities (opportunities) and threats (threats) in a project or a business venture. This process involves determining the specific goals of the business venture or project and identifying the internal and external factors that support and that is not in achieving that goal. SWOT analysis can be applied by analyzing and sorting out the various things that affect the fourth factor, then implement it in pictures SWOT, where the application is how the power (strengths) were able to take advantage (advantage) of opportunities (opportunities) that exist, how to overcome the weaknesses ( weaknesses) that prevents gain (advantage) of opportunities (opportunities) that exist, then how strengths (strengths) capable of facing threats (threats) of existing, and the last is how to overcome the weaknesses (weaknesses) are able to make threats (threats) to be real or create a new threat.

AHP (Analytical Hirarchy Process) developed by Thomas K. Saaty present a comprehensive and rational framework for managing the problem of making, presenting and to quantify the elements involved in the problem, create connectivity between these elements with the target (goal) public, and to evaluate alternative solutions, and set priorities or order of importance the elements referred to (Marimin, 2004). AHP is implemented based upon a number of criteria that were scored weighted by importance and influence of the presence of these criteria, as well as scores on a number of potential agricultural commodities (KPP) filed assessed according to each criterion there.

\section{Material And Methods}

This research was conducted in Tuban, in 20 districts. As the sample was selected 10 districts centers of production of fruits as samples in this activity. District that elected among others District of Soko, Grabagan, Semanding, Plumpang, Cross, Tambakboyo, Bancar, Bangilan, Kenduruan and Singgahan. Ten (10) districts are chosen each of the 3 villages, and each village selected two farmers as respondents. Total respondents 120 people, selected by purposive random sampling method. The research activities include product assessment base and non-base, farm analysis and assessment of the factors driving and inhibiting product of superior fruit. The analysis used in this research is the analysis of SWOT and AHP. SWOT matrix quantitative approach developed by Pearce and Robinson (1998) is useful to know the exact position of the actual commodity. The calculation is performed through three stages::

1. The calculation of scores (a) and weight (b) point multiplication factor as well as the total number of scores and weights to each factor S-W-O-T; Calculate the score of each point factor performed independent scale score range of options will determine the accuracy of the assessment, which is commonly used is 1 to 10 , assuming a value of 1 means the lowest score and 10 being the highest score. The calculation of the weight (b) each point factors implemented interdependence. That is, an assessment of one point factor is to compare the level of importance to the point of other factors in order to obtain formulations calculation. 
2. Perform a reduction in the number of total factor $S$ to $W(d)$ and factor $O$ with $T(e)$. Scoring $(d=x)$ hereafter becomes a value on the $\mathrm{X}$ axis, while the scoring $(\mathrm{e}=\mathrm{y})$ into a value on the $\mathrm{Y}$ axis

3. Describe the commodity positions indicated by the point (x,y) on the SWOT quadrant. The results of these calculations produce numbers coordinates in 4 quadrants.

Quantitatively, SWOT analysis using a matrix IFAS / EFAS, as follows:

1. Identify internal and external factors to do with qualitative descriptive analysis, by identifying the internal and external factors that become a strategic factor (strengths, weaknesses, opportunities, and threats) in the horticulture development strategies featured in Tuban.

2. Determination of the weight on the analysis of internal and external factors agriculture sector development strategy (food crops, plantation crops, livestock, forestry and fisheries) featured in Tuban done by asking questions to the informant / respondent are competent stakeholders related to it. Giving weight to do with the method of paired comparison (pairwise comparisons). Purwanto (2006), paired comparison analysis is a technique for comparing a component with other components in the same category on internal factors and external factors to obtain the value of the weight factor.

\section{Result And Discussion}

Analysis was conducted on horticulture in whole or in general. Deepening SWOT do not need to be done at this time, given its scope is quite broad and requires more detailed data in each district. Qualitative SWOT analysis is presented as follows:

Table 1. SWOT Matrix (IFAS / EFAS) Horticultural Commodity Tuban

\begin{tabular}{|c|c|}
\hline No & Description \\
\hline 1. & Strengths (S): \\
\hline 1.1. & Commodity Duku and Carambola has a unique / characteristic (comparative advantages) \\
\hline 1.2. & Agro-climate suitable for most commodities fruit and vegetables \\
\hline 1.4. & Road infrastructure between district and inter-provincial excellent \\
\hline 1.5 & Agricultural institutions supporting existing horticulture \\
\hline 2. & Weakness (W): \\
\hline 2.2 & Has not been supported by the adoption of environmentally friendly agriculture (organic) \\
\hline 2.3 & Lack of farm capital, particularly for medicinal plants and ornamental plants \\
\hline 2.4 & Lack of facilities and infrastructure of post-harvest and processing of crops \\
\hline 2.5 & Lack of research institutions that support the development and expansion of planting area featured product \\
\hline 3. & Opportunities (O): \\
\hline 3.1 & There is support for the policies and programs of the local government, provincial and national horticultural products \\
\hline 3.5 & Facility, access to market information and online promotions and trade fairs \\
\hline 4. & Threats (T): \\
\hline 4.1 & Competition in quality and price of similar products from other regions for most commodities seasonal vegetables and fruits \\
\hline 4.2 & Factors uncertain climate and the quality of soil fertility \\
\hline 4.3 & The impact of economic slowdown due to global economic crisis \\
\hline
\end{tabular}

Source: Processed Data, 2015

Based on the results of SWOT analysis, the relative position of horticultural products featured in Tuban are in quadrant I or quadrant aggressive. This indicates that the position horticulture Tuban quite superior and potentially developed in quantity and quality aspects. Recommendations given strategy is an aggressive strategy, which means horticulture in tip top condition and prospective, so it is possible to continue to expand the planting area, increase the growth and productivity gain more optimal. More detailed SWOT strategy required by the Government of Tuban in developing horticultural products are featured with S-O strategy that combines the strength of the economy to take advantage of opportunities that exist. The strategy carried out by the program or activity is as follows:

1. Extending the planting area of existing commodities, among others Duku Prunggahan, Belimbing Tasikmadu, and medicinal plants.

2. Increasing the productivity of fruit and vegetable seed, namely peppers, melons and watermelons.

3. Take advantage of new market opportunities for horticulture ie fruit and vegetable market that are environmentally friendly, produced through organic farming practices.

4. To increase the economic added value for farmers to apply post-harvest activities and processing. Especially processing large chilli / pepper, mango fruit, bananas and processing medicinal herbs for industry and cosmetics. 
5. Expanding horticulture marketing objectives through cooperation with big companies or exporters. It requires a special form of institutional marketing marketer of horticultural associations.

6. Establishing packing house and home marketing for farmers to be able to improve the quality of their products in the hands of consumers.

To realize these goals there are there are at least nine (9) of variables that must be considered in the development of superior products horticulture, namely the absorption of agricultural labor, raw materials in the form of land and inputs, capital, production facilities / enterprises, production technology, business management, market availability, the market price of the products and the contribution to the regional economy. Furthermore AHP analysis is used to determine a superior product which will get priority in its development in Tuban. Numerical assessment in this analysis is a way to facilitate the assessment and selection of variables in order to facilitate decision making. Based on calculations using AHP, priority development of superior products horticulture i.e. fruit belimbing, cayenne pepper and mango, as shown in Table 2.

Table 2. Priority Featured Product Development of Horticulture in Tuban

\begin{tabular}{|c|l|c|c|}
\hline No. & \multicolumn{1}{|c|}{ Commodity } & AHP score & Priority \\
\hline 1. & Belimbing & 1,54 & 2 \\
\hline 2. & Cayenne pepper & 1,36 & 3 \\
\hline 3. & Manggo & 1,35 & 4 \\
\hline 4. & Large red chilli & 1,31 & 5 \\
\hline 5. & Orange & 1,26 & 6 \\
\hline 6. & Melon & 1,24 & 7 \\
\hline 7. & Watermelon & 1,21 & 8 \\
\hline 8. & Duku & 1,18 & 9 \\
\hline 9. & Banana & 1,17 & 10 \\
\hline 10. & Guava & 1,14 & \\
\hline
\end{tabular}

Source: Processed Data, 2015

\section{Conclusions And Recommendations}

Based on the research we concluded that the strategy should be done is to improve and expand the planting area and also made various efforts to increase the productivity of fruit and vegetable seed. The study recommends that the processing should be performed yields superior products that add value and attractiveness increase, so will be the solution in increasing income and employment in Tuban.

\section{References}

[1]. Alfita, Riza. 2009. Decision Support System Design Prioritizing Regional Featured Product Method Using Weighted Product (WP). University Trunojoyo Madura.

[2]. Arsyad, L. 2002. Introduction of Regional Economic Planning (second edition). Yogyakarta: BPFE. UGM. Yogyakarta.

[3]. The Central Bureau of Statistics, 2014. Tuban in Figures 2014, Central Bureau of Statistics Tuban. Tuban.

[4]. The Central Bureau of Statistics, 2014. Tuban in Figures 2014, Central Bureau of Statistics Tuban. Tuban.

[5]. Planning and Regional Development Tuban, 2014. Potential and Superior Products Tuban. Tuban.

[6]. The Central Statistics Agency of East Java, 2014. The East Java Provincial Agriculture Indicators 2014. Surabaya.

[7]. East Java, Central Bureau of Statistics, 2015. Gross Regional Domestic Product (GRDP) Regency / City by Industrial 2010-2014 Surabaya.

[8]. Marimin. 2004. Methods for the Study of Development of SMEs Commodities. IPB and Bank Indonesia, Jakarta.

[9]. Pearce, Robinson. 1997. Strategic Management. Editions II. Jakarta : Bina Rupa Aksara.

[10]. Restiatun, 2009. Identification Sector Commodity And Inequality Inter-District / Municipality in DIY. Journal of Economics and Development Studies Volume 10, Number 1, 77 - 98. Yogyakarta.

[11]. Syafaat, N dan Supena F. 2000, Against Economic Crisis Impact Analysis of Employment and Identification of Leading Commodities Agricultural Sector in the region of Sulawesi: Input-Output approach. Economics and Finance Indonesia. Vol. XLVIII 14. 